\title{
XLV. New method for purifying coal gas, and at the same time increasing the product from a given quantity of coals
}

\section{Mr. S. Parker}

To cite this article: Mr. S. Parker (1818) XLV. New method for purifying coal gas, and at the same time increasing the product from a given quantity of coals, Philosophical Magazine Series 1, 52:246, 292-293, DOI: 10.1080/14786441808652049

To link to this article: http://dx.doi.org/10.1080/14786441808652049

曲 Published online: 23 Jul 2009.

Submit your article to this journal $[\pi$

Џll Article views: 2

Q View related articles $\sqsubset$ 


\section{[ 292$]$}

XLV. New Method for purifying Coal Gas, and at the same time increasing the Product from a given Quantity of Coals. By Mr. S. PARKer, Liverpoal.

\section{To Mr. Tilloch.}

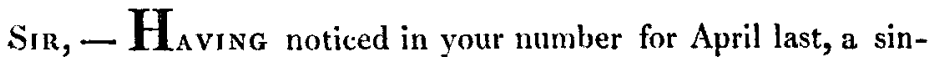
gular method of purifying coal gas, I take the liberty of communicating to you some additional facts which cannot be wholly uninteresting to those who are engaged in the new and wonderful art of procuring light. Having made the crude coal gas to pass through an arrangement of three iron pipes placed horizontally in a furnace, and kept at a dull red heat, being connected together with a gun-barrel ; I found to my great astonishment that the quantity of gas that could be obtained by this means from a given quantity of coal greatly exceeded the quantity obtainable in the usual manner; and further, that the gas was perfectly pure, whilst the quantity of tar produced during the process was considerably less than what is obtained in the ordinary gas-light process. The fluid, which was collected in a vessel interposed between the extremity of the ignited iron pipes through which the gas passed, and the gasometer which received it, contained no vestige of ammoria; but on the contrary, it instantly reddened litmus paper. It possessed an acid styptic taste, and a pungent sulphureous odour. It was of a black colour; and when largely diluted, produced an insoluble precipitate with muriate of barytes. It was sulphuric acid. It is therefore evident that crude coal gas, when made to traverse an ignited iron tube, suffers a remarkable change. The sulphuretted hydrogen gas, which always accompanies this gaseous fuid as obtained from coal, no doubt becomes decomposed during the process, and to it the production of the sulphuric acid must be attributed; -but by what means this decomposition is effected, would not become me to state. It is evident that not only the sulphuretted hydrogen, but the ammonia also, is decomposed; hecause the fluid which distils over is not alkaline, but decidedly acid. And muriate of barytes and acetate of lead show that it contains sulphuric acid strongly loaded with sulphureous acid gas.

The increase of gas, there can be no doubt, must be attributed to the decomposition which the tar suffers during this process; for it is sufficiently evident that this substance may be wholly converted into oxycarburetted hydrogen gas.

The gas thus produced is perfectly free from sulphuretted hydrogen, as well as from carbonic acid; for it neither disturbs the transparency of a solution of super-acetate of lead, nor barytic water, when made to pass through it. From these considerations 
there is reason to believe that the purification of coal gas, the application of which is daily increasing as a substitute for procuring light, might be effected in a more oeconomical manner, by causing the gas to traverse ignited iron vessels, than by the application of quick-lime. The subject is worthy of a strict examination, both in a philosophical point of view, as well as with regard to practical utility. I have the honour to be, sir, Your obedient servant,

Liverpool, Sept. 3, 1818.

S. PARKER.

\section{Improvement in the Method of forming Electrical. Planispheres. By Mr. Rowland HiLta.}

\section{To Mr. Tilloch.}

Sir, - Nearly four years ago I had occasion to represent some of the constellations and other figures by electricity. $\mathrm{Hi}$ therto this had always been done upon glass; but 1 wished to construct the constellations on a scale which required larger plates of glass than I conld conveniently procure. Paper being a nonconductor of electricity, I was induced to make trial of it, and found that it answered my purpose exceedingly well. At that time I constructed four constellations, viz. the Great Bear, the Great Dog, the Ship, and the Scorpion. I made use of that kind of paper which is called Bristol board; the tin-foil may be stuck upon it in the same manner as it is fastened to glass. I also found gold size (a liquid used by the gilders) to be very well adapted to that purpose; and the figures may be secured more completely by covering the whole with a coat of vamish. Since that time I have represented upon paper a considerable portion of the southerr sky. I took several sheets of drawing-paper, pasted the edges together, and stretched the whole upon a circular woolen frame four feet in diameter. Upon this apparatus are represented all the stars of the four first magnitudes within forty degrees of the south pole.

In order to give to the stars of the different magnitudes their proper degrees of relative brightness, I took the following method.

For the stars of the first magnitude, I cut the ends of the tinfoil round, and placed them about one-twelfth of an inch asunder. For those of the second magnitude, the bits of tin-foil were pointed, and the spaces between them made a's small as possible. To produce a spark of no greater brightness than the stars of the third inaguitude, I made the spaces in the tin-foil similar to the last, and pasted over each a small bit of thin paper, through which 